\title{
Early and Middle Pleistocene pollen assemblages of deep core drillings in the northern Upper Rhine Graben, Germany
}

\section{Knipping}

Institut für Botanik (210), Universität Hohenheim, D-70593 Stuttgart, Germany. Email: knipping@uni-hohenheim.de

Manuscript received: February 2005; accepted: August 2007

\begin{abstract}
Recent core drillings, carried out during water-economic exploration in the area of Mannheim/Ludwigshafen/Schifferstadt (Rhine-Neckar region, Germany), have produced a more differentiated stratigraphic division of the Pleistocene sediments of the northern Upper Rhine Graben. Pollen analytical investigations as well as malacological, heavy mineral, palaeomagnetic and lithological research have led to a stratigraphic reinterpretation of the gravel layers and intermediate horizons. Based on the results of the pollen analyses, the Mannheim interglacial period in the upper intermediate horizon (Oberer Zwischenhorizont, $\mathrm{OZH}$ ) cannot be assigned to the Eemian as stated earlier. The occurrence of Fagus, Celtis and Azolla, along with the results of malacological analyses, indicate a Cromerian age for the Mannheim Interglacial. In addition, a pollen sequence from a different interglacial in the core sediments from Schifferstadt could also be assigned to the Cromerian. The Schifferstadt Interglacial is divided into a lower optimum phase with high values of Ulmus, Quercus and Corylus while Carpinus is completely absent, and an upper optimum phase with low values of Carpinus. Fagus is absent in the whole sequence. The 0ZH comprises not only the two interglacial pollen sequences described above but also parts of at least four Middle Pleistocene Interglacials. In the lower part of the drillings in Schifferstadt and Ludwigshafen, which are assigned to the Early Pleistocene, pollen assemblages with Fagus are likely to correlate with parts of the Tiglian A substage. There is a clear change to a Tertiary type of pollen flora at $91 \mathrm{~m}$ at Schifferstadt and at $186 \mathrm{~m}$ in Ludwigshafen.
\end{abstract}

Keywords: Pollen analysis, Early Pleistocene, Middle Pleistocene, Upper Rhine Graben, Germany

\section{Introduction}

The Upper Rhine Graben is a zone of tectonic subsidence. Thick layers of sediment have been deposited since the Eocene particularly in the western part of the investigated area, where increased subsidence took place during the Tertiary period. In the Heidelberg/Mannheim area the Pliocene and Pleistocene layers were formed during a younger phase of subsidence of the basal deposits.

The lithogenic-petrographic sequence of Pliocene and Quaternary layers in the study area (Fig. 1) has been intensively investigated, and a stratigraphic division has already been established (Bartz, 1959, 1982; Kärcher, 1987). The Tertiary layers are characterised by silt and clay, whereas the Quaternary deposits comprise gravel, sand and finer grained sediments (silt, clay, organic horizons). The division into lower, middle and upper aquifers (gravel layers, Kieslager) and intermediate layers (Zwischenhorizonte) is based on lithological data. Interdisciplinary studies in the northern part of the Upper Rhine Graben have been described in a special publication (Von Koenigswald, 1988), dealing with the lithological-stratigraphic sequences, as well as the remains of Upper Pleistocene mammals, snails, wood and pollen. Pollen analytical investigations of sediments deposited prior to the Holocene were only possible within the scope of water-economic and raw material explorations. Previous studies were often carried out on isolated, single samples which produced limited evidence (Von der Brelie in: Bartz, 1976, 1982; Hottenrott, 1995). More recently undertaken pollen analytical studies (Schedler, 1981; Küttel et al., 1986; Beug, 1988; Bludau, 1993, 1995; Knipping, 2002, 2004a, 2004b) have led to an increase of knowledge and a differentiated point of view. For example, the study of Steinbach (Schedler, 1981) led to a revision of the former Holsteinian age to a position within the Cromerian 


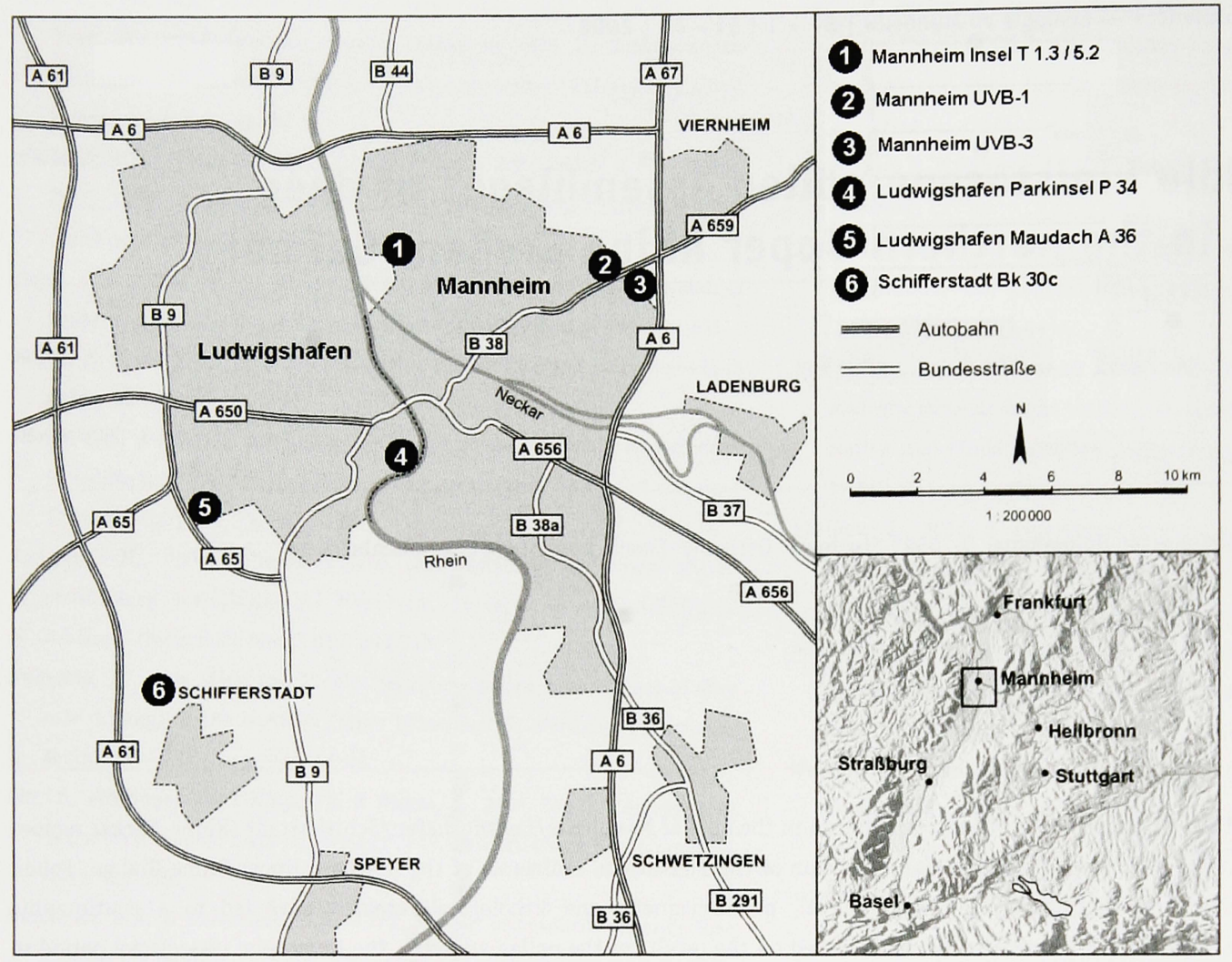

Fig. 1. Location of investigated sites (for geological setting see: Weidenfeller \& Kärcher, 2008).

Complex. Bludau $(1993,1995)$ analysed predominantly Early Pleistocene sediments in the central part of the Upper Rhine Graben, and described three interglacial sequences from Tiglian A to Bavelian. But so far, most of this pollen data has not been published. Isolated pollen assemblages representing boreal forest or phases of open vegetation have been analysed by several authors (Beug, 1988; Bludau, 1993; Knipping, 2002, 2004, unpublished data), but until now a correlation with welldefined sequences has not been possible. From the upper aquifer (OKL) only the pollen sequence of Rösbach with a boreal forest could be dated by ${ }^{14} \mathrm{C}$ to the Würmian (Küttel et al., 1986). Several single samples, indicating mainly boreal conditions, were dated by the U/Th method to between $118 \mathrm{Ka}$ and $279 \mathrm{Ka}$ (Beug, 1988; Schweiss, 1988). However, the exact stratigraphic position of these samples is uncertain since they were recovered during dredging activities below the groundwater table. Validated pollen sequences representing the Eemian in the Upper Rhine Graben have never been described, although several profiles thought to date to this period have been analysed (Bludau, 1993; Knipping, 2002, 2004a, unpublished data).

Pollen analytical investigations on the fluvial deposits of the Rhine raise many problems. The sequences are frequently incomplete due to discontinuous sedimentation, erosion and reworking of sediments, and the fact that only organic or finegrained sediments are conducive to the preservation of pollen. In addition, there are uncertainties when comparing the results of pollen analyses from the Upper Rhine Graben with those from northwestern Germany and the Netherlands because of the warmer climate of the Upper Rhine Graben and the near migration way through the Rhone-Rhine system.

In Central Europe long terrestrial pollen sequences comprising several successive warm and cold phases are rare (Menke, 1975; Welten, 1982, 1988; Müller, 1986, 1992; Grüger et al., 1994; Reille \& de Beaulieu ,1995; Urban, 1995, 2006). Therefore the deep drillings in the Upper Rhine Graben are of special interest for stratigraphic subdivisions. The current interdisciplinary studies (Hagedorn \& Boenigk, 2004, 2008; Weidenfeller \& Kärcher, 2004, 2008; Rähle, 2005; Rolf, 2004, 2008) will contribute to a better understanding of the Early and Middle Pleistocene stratigraphy in this area.

\section{Methods}

The larger part of the investigated samples is derived from cored drillings. The preparation of the Mannheim samples has been carried out at the University of Hohenheim and the samples from Schifferstadt and Ludwigshafen at the laboratory of LGB Rheinland-Pfalz. Important results are presented in this paper in form of pollen diagrams, which are all depicted in the same manner and show only reduced pollen spectra. The reference sum for calculation includes all terrestrial plants except local elements (such as Cyperaceae, aquatic taxa) and spores. Pollen preservation is widely differentiated and indicates the conditions under which sedimentation took place. PreQuaternary taxa and indeterminable types can be used as indicators of redeposited sediment. 


\section{Results}

\section{Borehole Schifferstadt}

Schifferstadt BK 30c GM, core drilling $0-200 \mathrm{~m}$, (OZH $5.3-49.0 \mathrm{~m})$ (Fig. 1)

The Schifferstadt sequence comprises mainly finely-grained sediments (silt, clay, sand); gravel is rare. The heavy mineral spectra of the upper $6.5 \mathrm{~m}$ are of Alpine type, and represent an embankment of the river Rhine. Local, non-calcareous sediments from the Pfälzer Wald are present to a depth of $77 \mathrm{~m}$. Rhine deposits are predominant calcareous and occur between 77 - 91 m. Below 91 m non-calcareous Pliocene Sediments appear (Hagedorn, 2004; Hagedorn \& Boenigk, 2008).

\section{S-I-A + B, Schifferstadt Interglacial, $21.82-24.14 m$} (Fig. 2, 8)

The pollen diagram can be divided into 10 local pollen assemblage zones (PZ).

The sequence starts with a typical late-glacial pollen flora (Juniperus, Betula, Artemisia), but the immigration phase of thermophilous taxa is not represented (PZ 1). The interglacial sequence is divided into a lower optimum phase with high values of Ulmus, Quercus and Corylus while Carpinus is completely absent (PZ 2, 3), and an upper optimum phase with low values of Carpinus ( $\mathrm{PZ} \mathrm{9,10).} \mathrm{Fagus} \mathrm{is} \mathrm{absent} \mathrm{in} \mathrm{the}$ whole sequence, and Celtis is rare. In pollen assemblage zone 5 reworking of sediment has probably led to the poor preservation of thermophilous taxa, resulting in increases in the amounts of indeterminable pollen and low pollen concentrations. It is uncertain if reworking took place under interglacial or stadial conditions. In the latter case, this sequence may represent two separate interglacials.

\section{S-I-C, Schifferstadt, $36.21 \quad 36.58 \mathrm{~m}$ (Fig 3, 8)}

The short sequence within the 0ZH layers of sandy silt can be divided into two pollen zones. In the lower zone Betula, Pinus, Alnus and Picea dominate the arboreal spectrum with low values of thermophilous trees and Tsuga. Higher values of Pinus and increasing Tsuga pollen characterises the upper zone. NAP (non arboreal pollen), mainly of Poaceae and Ericales is frequent in both zones.

\section{S-I-D, Schifferstadt, $51.71-52.34 \mathrm{~m}$ (Fig. 4, 8)}

In contrast to the oceanic phase with Tsuga mentioned above, several sections can be detected which indicate continental climate (Larix, Ephedra, Artemisia, Chenopodiaceae). During these phases Ericales and Tsuga are rare or absent.
S-I-E Schifferstadt, $80.21 \quad 84.53 \mathrm{~m}$ (Fig. 5, 8)

The sediment in this section consists of mainly clayey, sandy silt alternated with darker layers containing a high organic component derived from redeposited Tertiary material.

The pollen diagram in Figure 5 can be divided into four major zones. The first zone ( $\mathrm{PZ} 1$ ) includes a pollen assemblage of Pinus, Pinus cembra type, Pliocene taxa, reworked preQuaternary taxa and a high amount of indeterminate types. The second zone ( $\mathrm{PZ} 2$ ) comprises high values of Ulmus and lower amounts of Pinus. The third zone (PZ 3 ) is characterised by high values of Picea, Picea omorica type, Pinus and Pinus cembra type and a regular occurrence of Fagus. The upper zone (PZ 4) shows lower values of Pinus cembra type, while counts of Fagus attain more than $10 \%$ in two samples. In the upper two zones, samples apparently containing reworked Tertiary pollen are visible (see arrows in the diagram, Fig. 5). Higher amounts of indeterminate taxa, pre-Quaternary taxa, and few spores of the Pliocene relict Verrucatosporites (Menke, 1975) support this assumption. In samples without reworked taxa pollen concentration is low, but preservation is good. Reworked Tertiary pollen is present throughout both of the lower sections. The reworking of older material means that it is difficult to assign the pollen types to autochthonous or allochthonous taxa. In PZ 2 Ulmus seems to be autochthonous, as well as Picea, Picea omorica type, Pinus, Pinus cembra type, Fagus, Tsuga and Eucommia in PZ 3 and 4.

A Pliocene pollen flora with high values of Tertiary elements is present below $91 \mathrm{~m}$. This stratigraphic position is confirmed by heavy mineral analysis (Hagedorn, 2004).

\section{Boreholes Mannheim}

Several sites have been investigated in the Mannheim area (Fig. 1; Knipping, 2004a) and some of the results of these investigations are presented in this paper (Fig. 6, 7).

\section{M-I-A, Mannheim UVB-3, $34.1 \mathrm{~m}$ (OKL $0-42.5 \mathrm{~m})$}

(Fig. 8)

An interglacial pollen assemblage with Pinus, Betula, Picea, Quercus, Carpinus, Abies, Fagus and Buxus could be determined in a single sample of fine-sandy sediment within the upper gravel layer (0KL). Pterocarya pollen is not present in this sample.

M-I-B + C, Mannheim UVB-3, 42.52 - $43.6 \mathrm{~m}$, core drilling (OZH $42.5 \mathrm{~m} \geqslant 43.60 \mathrm{~m}$ ) (Fig. 6)

The pollen diagram can be subdivided into two zones. In the lower zone (M-I-C, PZ 1) the deposits comprise calcareous, slightly humic silts and in the upper zone (M-I-B, PZ 2) silty humic non-calcareous clays. At $42.98 \mathrm{~m}$ intercalated sand and gravel in between the two layers probably indicates a 
səuoz uəןod

\begin{tabular}{|l|l|l|l|l|l|l|l|l|l|}
\hline$\circ$ & 0 & $\infty$ & $\sim$ & 0 & $\infty$ & + & $\infty$ & $\sim$ & - \\
\hline
\end{tabular}

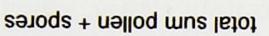

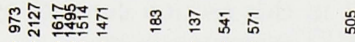
पIIIIDL

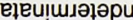

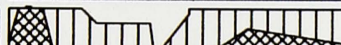

unu6euds u!ढejəs e\||әu!ढejəS epunuso

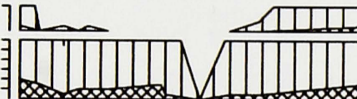

snovosokiog

әе|nssew e!u!nı|es<smiles>[AlH2]</smiles>

م=

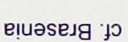
eəeudu/N

un॥Kudo! $1 \times W$

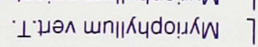

eie!|익 sauluekuaw

$\perp$ e!|0!!ne eud $K_{\perp}$

$\perp$ un!̣uebıeds

әеәэеләdК弓

uns əันәرコృ

แกңэ!|ечц

$\perp$ әеәэе!podouəuว

s!̣|ə弓

səia

snuidue?

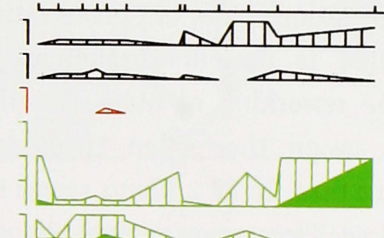

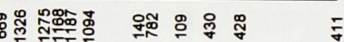

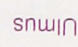

‼!
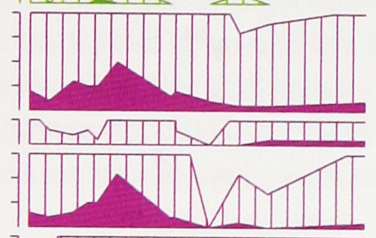

snวəก๊o

snikioj

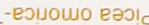

әeydodd! $\mathrm{H}$

L-eXYวe]sip eıpayd
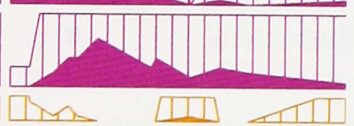

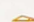

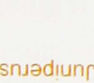

xiles

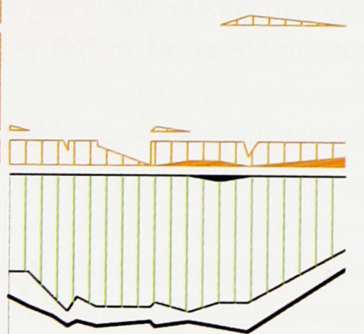

s

[w] ułdəp

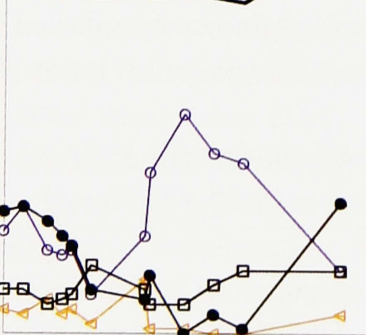

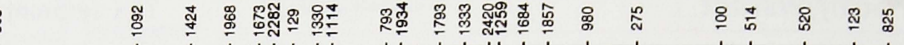

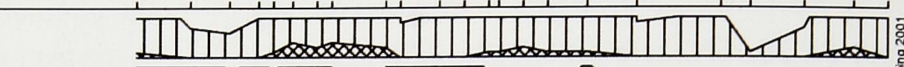

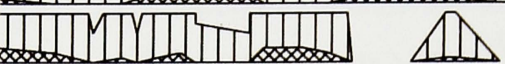

म

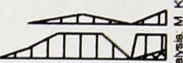

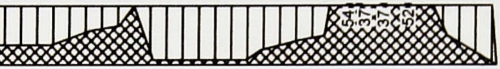

Ind 10

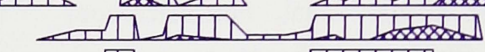

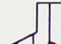

2

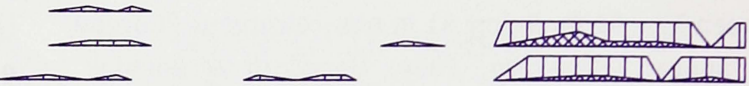

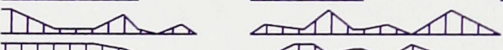

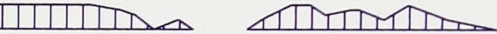

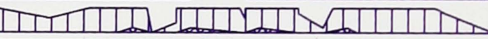

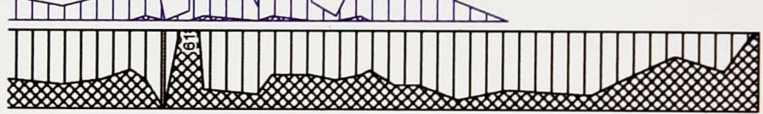

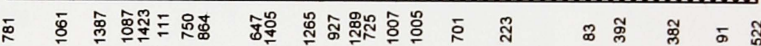
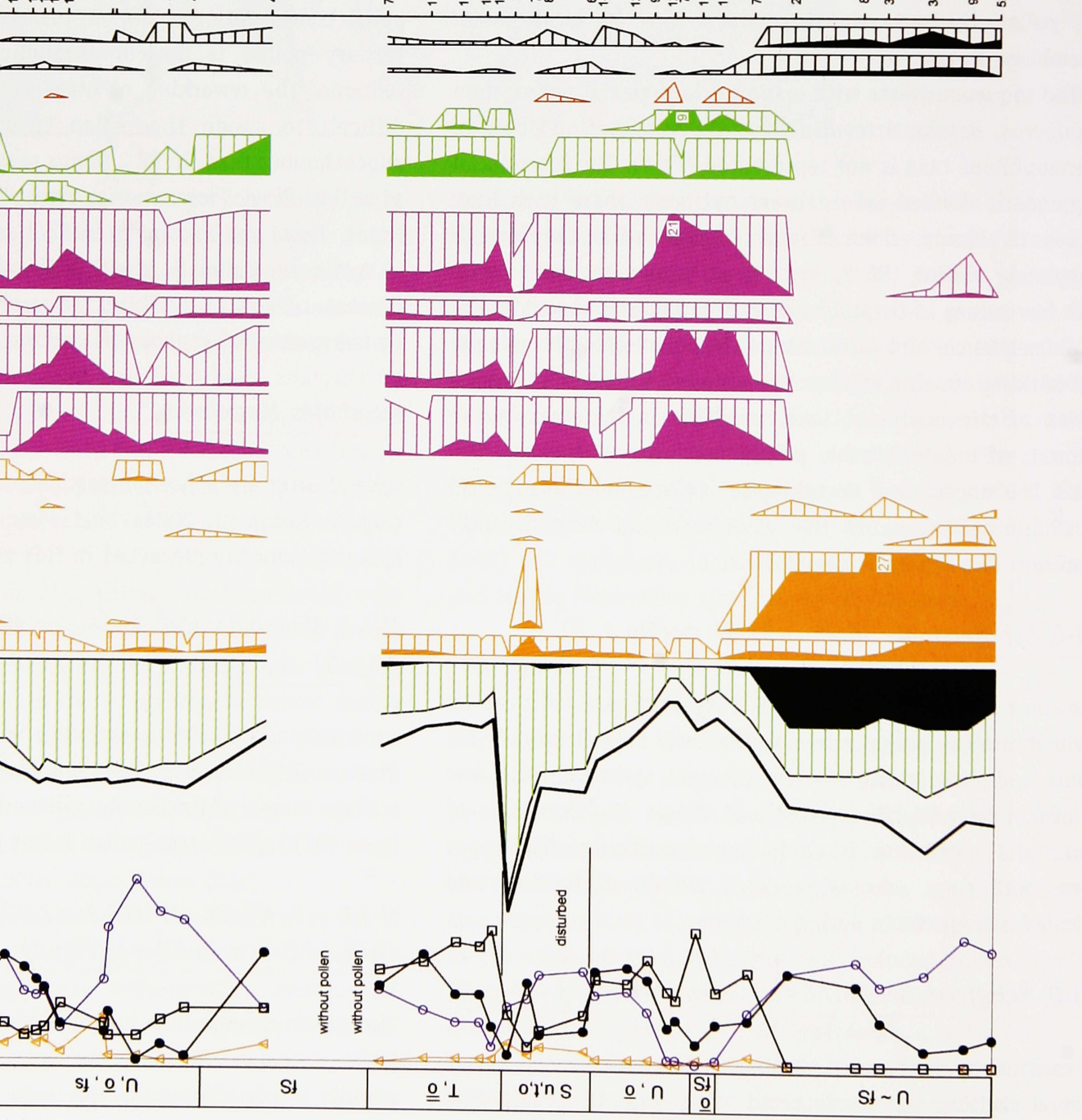

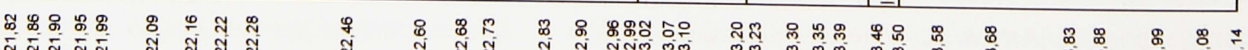


discordance in the deposits. The pollen assemblage in PZ 1 is characterised by Alnus, Carpinus, Ulmus, Corylus, Quercus and Taxus. Remarkable are the occurrence of Vitis and single grains of Celtis and Tsuga. Pollen preservation is variable but there is hardly any indication of reworked taxa. The presence of still or sluggish water is indicated throughout the sequence by the

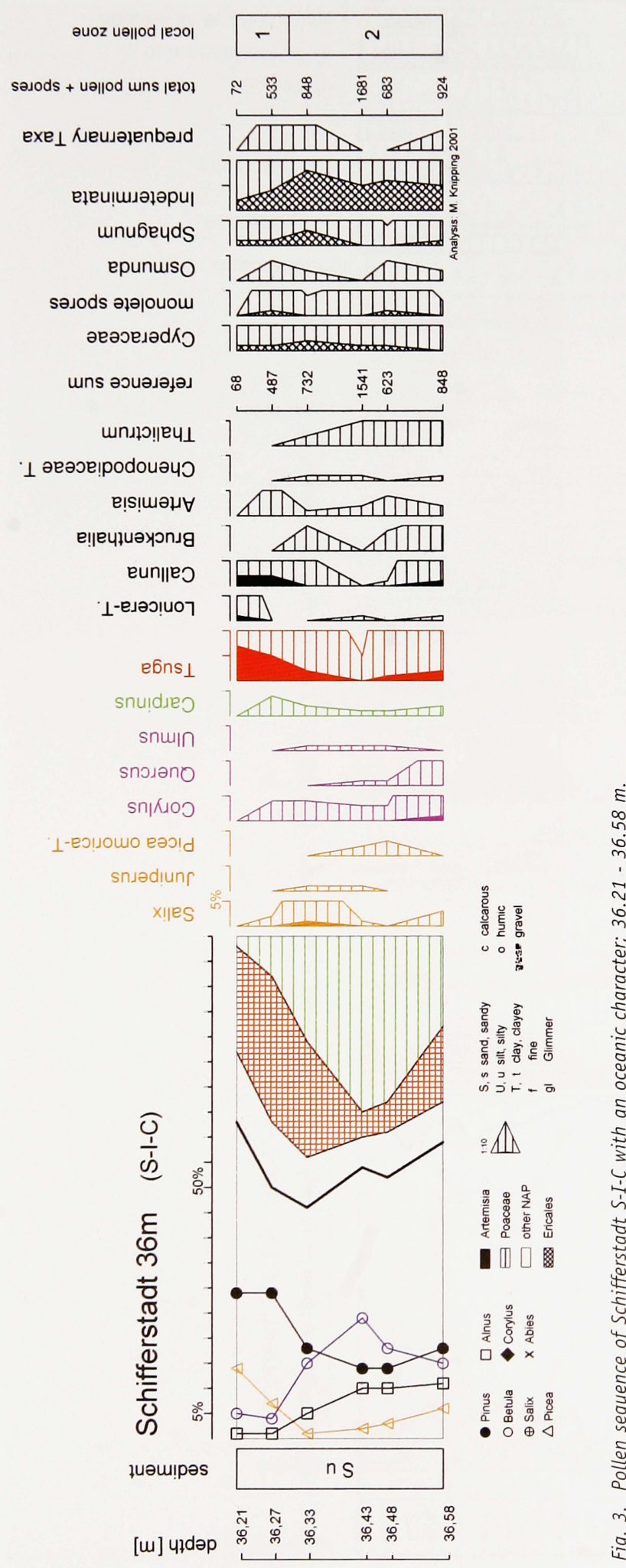

occurrence of Nymphaea, Nuphar, Potamogeton, Brasenia, Myriophyllum and Azolla. With the change of sediment the character of the pollen assemblage also changes, as is indicated by the high values of (local) Alnus, Abies and Fagus in PZ 2. Celtis is present, single massulae of Azolla and Salvinia indicate still eutrophic water and warm summer conditions.






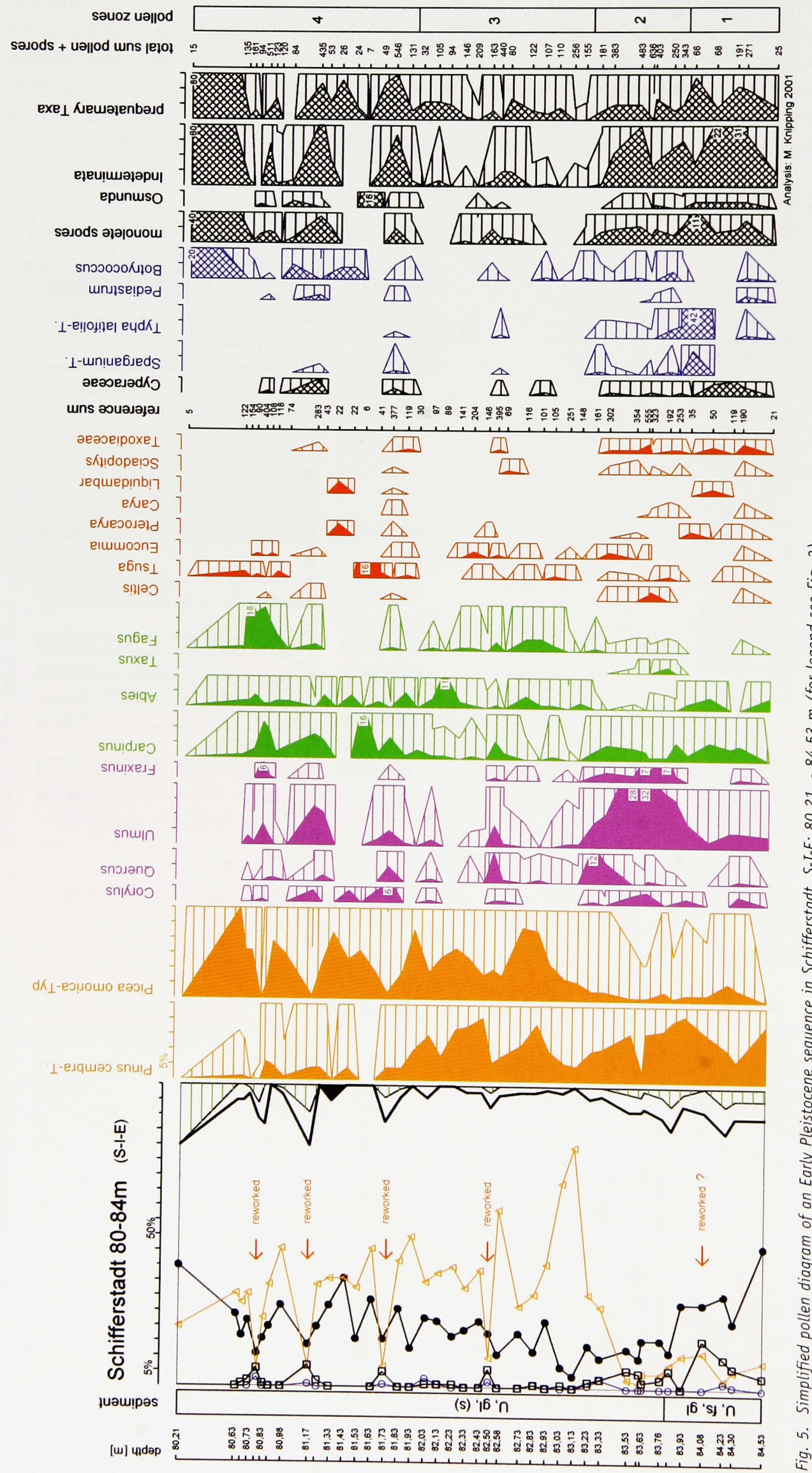




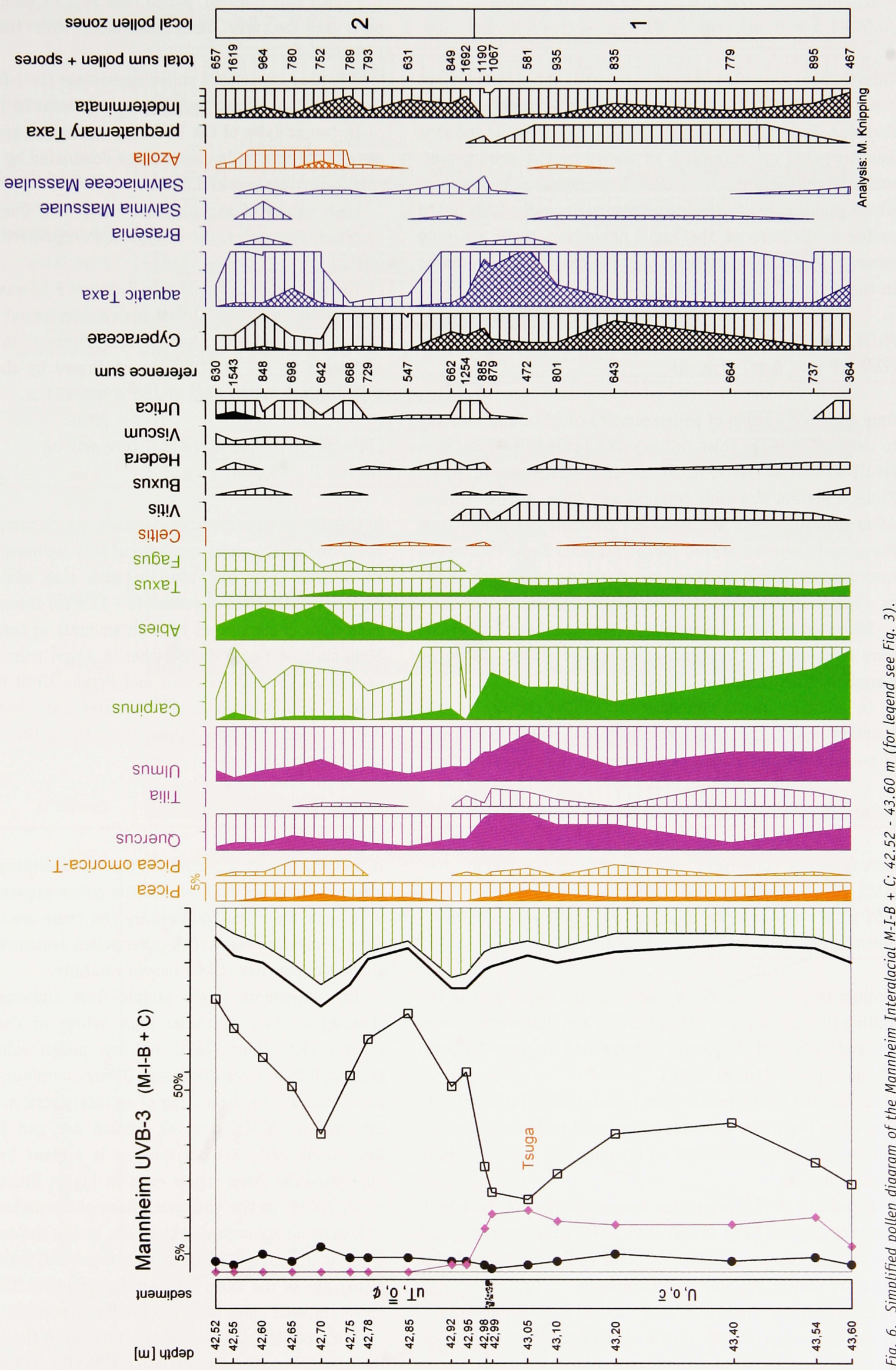


This section comprises mainly sand with intercalated plant remains. The pollen assemblage with Alnus, Abies, Corylus, Carpinus, Taxus and low values of Celtis, Fagus, Buxus and Vitis was deposited rather rapidly as shown by the good preservation of the plant remains. These were deposited in the sand, which probably led to the low concentrations of pollen in the sediment. Because of the rapid deposition there are only minor changes in the sequence, and the time-span represented in the sediment may be short.

M-III, Mannheim Insel T 1.3/5.2, flush drilling $0-124 \mathrm{~m}$ (OZH $26-44.5$ m) (Fig. 8)

Only a limited number of pollen samples could be analysed due to the nature of the flush drilling. The samples from 29/30 m (M-III-A) and $42 \mathrm{~m}$ (M-III-B) are of special interest, where Fagus is present alongside Carpinus and Abies. At the depth of $44 \mathrm{~m}$ (M-III-C) Abies and Picea are frequent but pollen from Fagus and Carpinus are no longer present. Early Pleistocene taxa were not found in several samples down to a depth of 124 $\mathrm{m}$, except for some fragments of Tsuga at $99 \mathrm{~m}$.

Pollen assemblages comparable to the Mannheim Interglacial were recovered from several single samples of the $0 \mathrm{ZH}$ in the Mannheim area (Knipping, 2004a).

In addition short sequences or single samples in the Mannheim and Ludwigshafen boreholes with pollen assemblages of boreal forests or stadial vegetation are common (Fig. 8).

\section{Boreholes Ludwigshafen}

Ludwigshafen Parkinsel $P$ 34, core drilling $0-300 \mathrm{~m}$

(OZH $12.8-39.35 \mathrm{~m}, \mathrm{ZH} 2+\mathrm{ZH} 339.35=91.6 \mathrm{~m}$,

UZH $91.6-177 \mathrm{~m}$ ) (for location see Fig. 1; results are given in Fig. 8)

Medium to coarse gravels only occur in the upper part of the drilling $(0-12.8 \mathrm{~m})$. The $\mathrm{OZH}, \mathrm{ZH} 2, \mathrm{ZH} 3$ and $\mathrm{UZH}$ are composed of sand, silt and clay with intercalated organic horizons (Weidenfeller \& Kärcher, 2008).

In the $\mathrm{OZH}$ of the profile from Ludwigshafen Parkinsel P 34 (Fig. 8) at least four different interglacial pollen assemblages can be recognised, although so far only parts of these have been analysed.

At a depth of $13.6 \mathrm{~m}$ a pollen assemblage (Lu-I-A) with high values of Corylus (22\%) as well as Picea (17\%), Alnus (26\%) and low values of Quercus, Ulmus, Carpinus and Abies may indicate the early part of an interglacial sequence.

Especially the section at $26.529 .05 \mathrm{~m}$ is of importance. In the lower part of this section (Lu-I-C) pollen from Abies, Carpinus, Taxus and massulae from Azolla are present and in the upper part (Lu-I-B), pollen from Fagus appears. These two parts can be very likely correlated with the Mannheim Interglacial.

A further interglacial pollen assemblage (Lu-I-D) with Picea, Quercus, Alnus, Ulmus and Corylus is present at $37-38 \mathrm{~m}$.

In two samples of the UZH $(103 \mathrm{~m})$ several grains of Tsuga were found in a pollen assemblage dominated by Pinus alongside Picea, Carpinus and Ulmus.

High values of Fagus pollen along with Quercus, Ulmus, Carpinus, Pterocarya, Ostrya type and Tsuga were recovered at $161 \mathrm{~m}$.

The drilling of Ludwigshafen Parkinsel P 34 was constructed down to $300 \mathrm{~m}$. Heavy mineral analysis carried out by Hagedorn (2004) detected the change from Pliocene to Pleistocene sediments at $177 \mathrm{~m}$. This was confirmed by single samples with Tertiary pollen flora at $186 \mathrm{~m}$ and $201 \mathrm{~m}$.

\section{Ludwigshafen-Maudach A 36, core drilling (OZH 6.0 - 49.6 m) (Fig. 8):}

In the $\mathrm{OZH}$ at Ludwigshafen-Maudach, which comprises mainly sands and silts, a short sequence of silty sediments covered by an organic layer and overlain with clay could be partly analysed. The pollen sequence $(9-11.2 \mathrm{~m}$ ) shows interglacial conditions characterised by high amounts of Carpinus (up to $40 \%$ ) shifting to woodland richer in Abies, then in Picea and dominated at least by Pinus and Betula. Until now Fagus is absent, even though several samples have been analysed. Pollen of Buxus attains values up to $5 \%$ in the lower part of the interglacial.

\section{Discussion}

It should be stressed in advance, that the following correlations are only tentative in character. The pollen sequences recorded up to now are often fragmentary and there are uncertainties when comparing these with other pollen sequences. Especially single samples have to be judged carefully.

The uppermost single sample from Ludwigshafen P 34 (Lu-I-A) at $14.6 \mathrm{~m}$ shows high values of Corylus (22\%), Picea $(17 \%)$, Alnus $(26 \%)$ and low pollen values of other thermophilous trees (Quercus, Ulmus, Carpinus, Abies) and could indicate the beginning of an interglacial or a temperate interstadial. A Holocene or Eemian age can be excluded. During the early Eemian Quercus is present before Corylus appears while Picea is low even in higher altitudes (Müller, $2000,2001)$. In the youngest phase of the Holocene Picea is always being accompanied by Fagus, and in the early Holocene there is almost no Picea in this region. A correlation with either one of the Early Würmian interstadials MIS $5 \mathrm{a}$ or $5 \mathrm{c}$ or an interglacial older than the Eemian is possible.

The interglacial sequence ( $9-11.2 \mathrm{~m}$ ) in the upper part of the $0 \mathrm{ZH}$ at Ludwigshafen-Maudach A 36 (Fig. 8) has been partly 


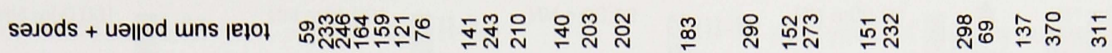
iิ $\stackrel{1}{1}$

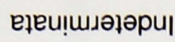

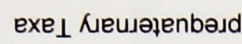
səدods 리인 unıse!̣pəd әе|nssew eluin|ㄹes słue|d ләңем әеәэеләdК弓 uns əวนәมอุว еләрән snxng

S!!!^ ร!ฺ|əว snbey snxe $\perp$

snuịdej snuin

ไuəu!̣pอs

[w] 4ұdəp

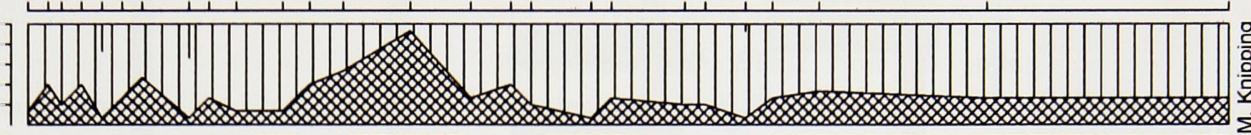

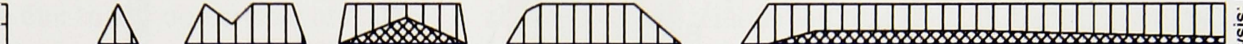

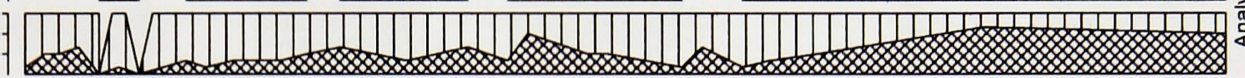

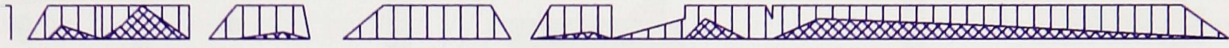

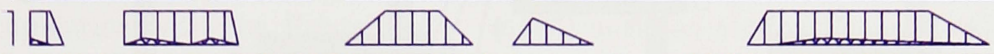

1 L L

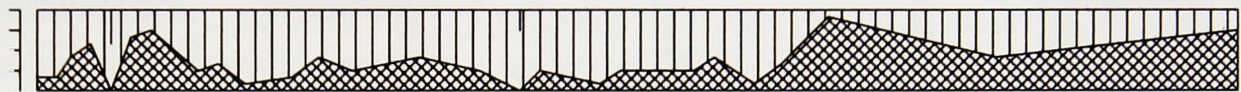

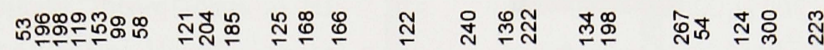

ร

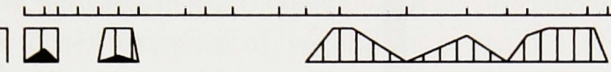

$70 \Delta \Delta$

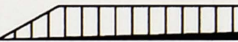
1 पl

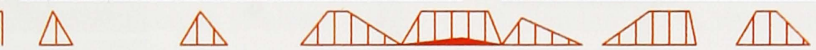
$\triangle \triangle 1 \backslash \square \square$

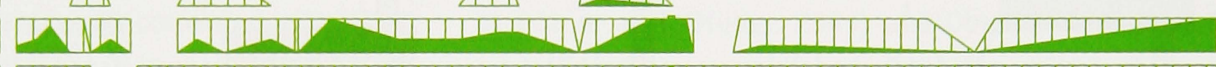

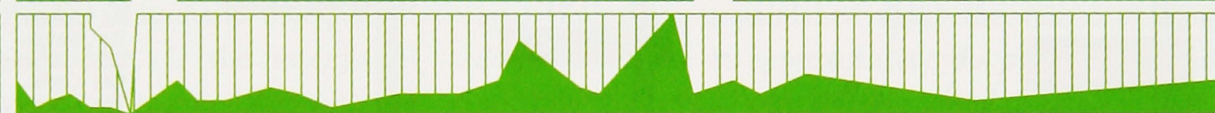

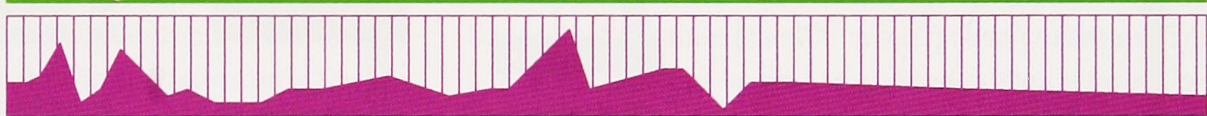

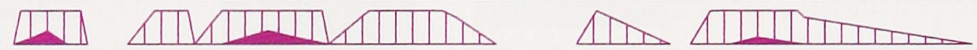

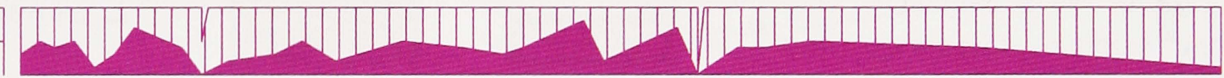

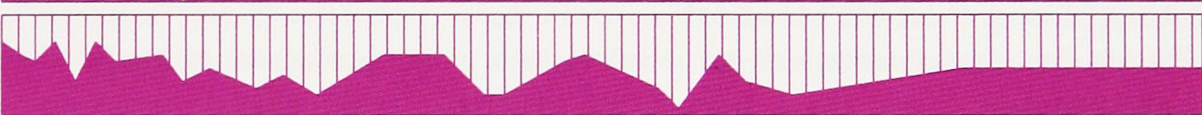

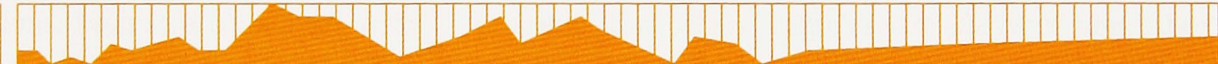
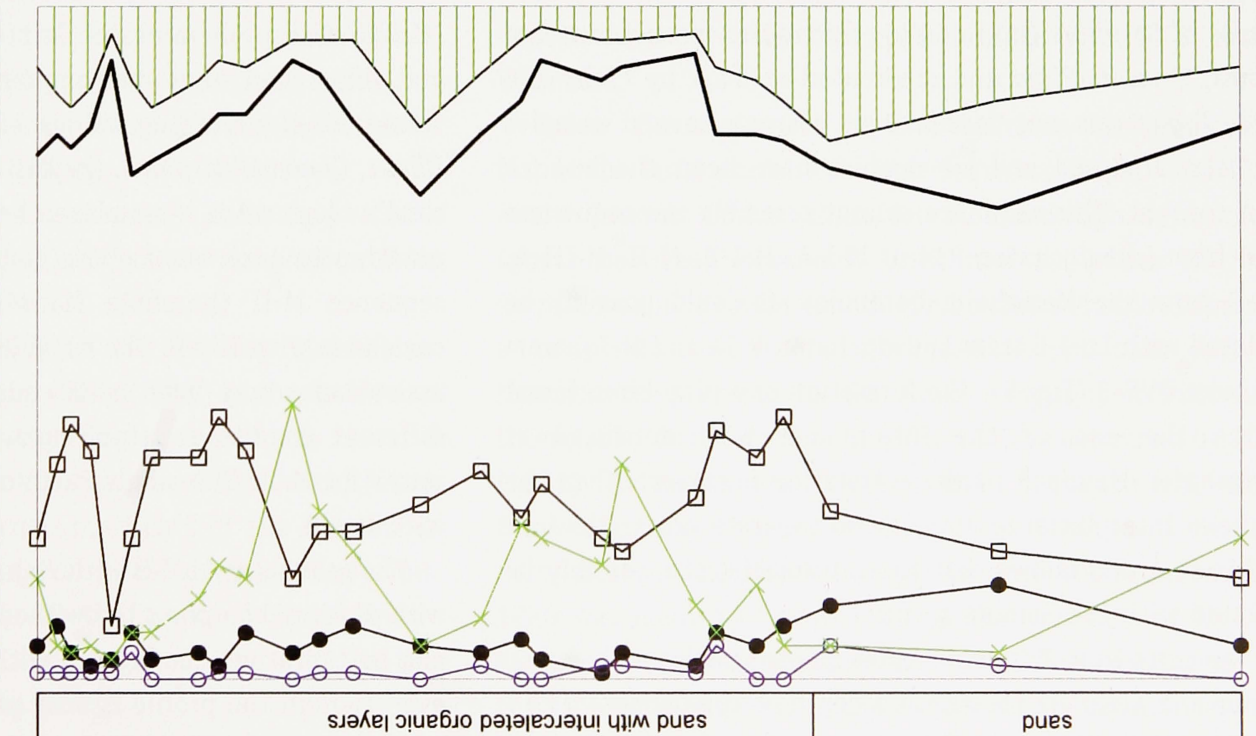

pues

요 \&

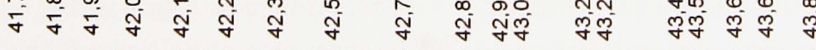



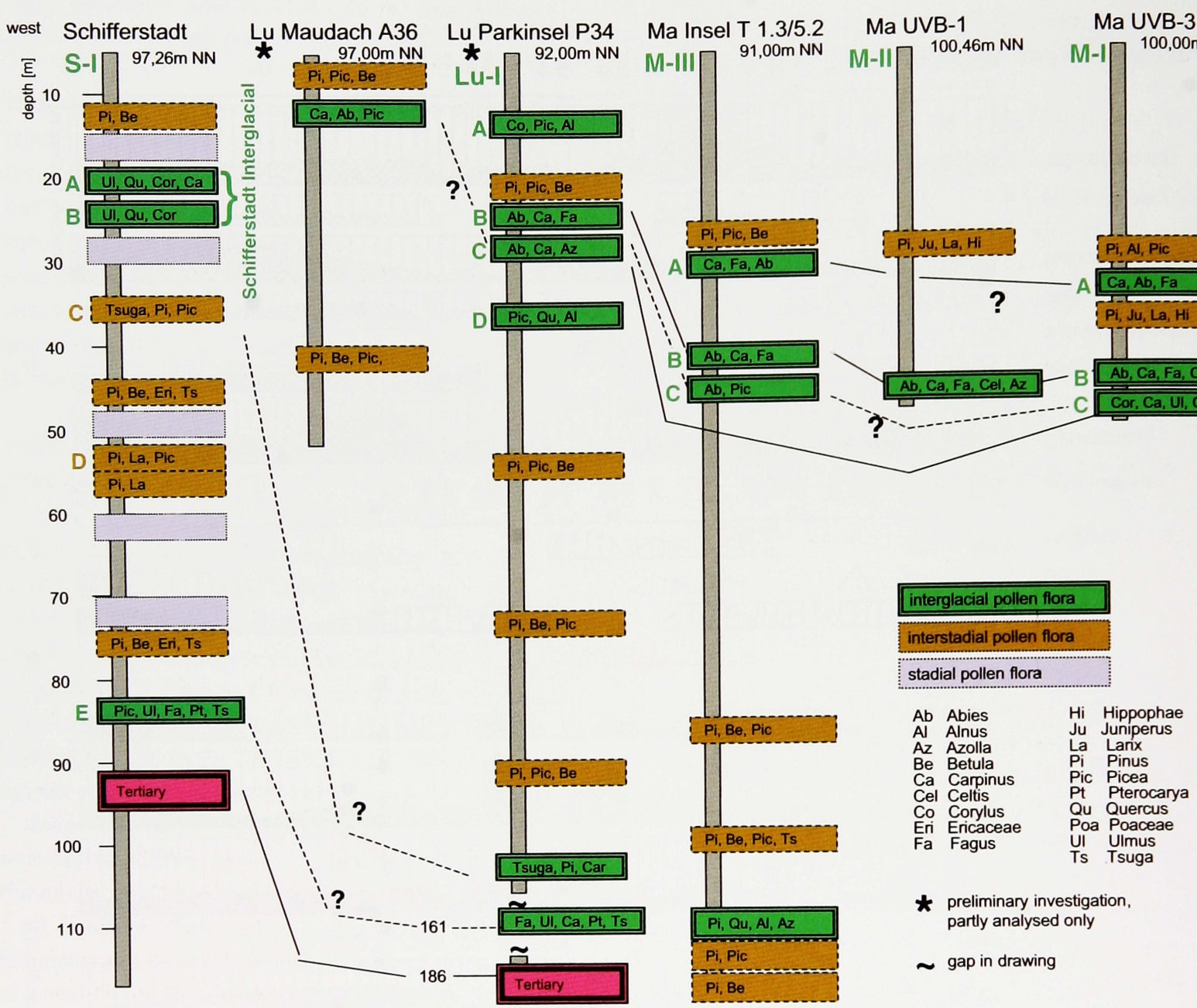

Fig. 8. Overview of investigated profiles in the Mannheim area with a preliminary correlation ( $A, B, C$ and $D$ refer to discussed sections, see text for further explanation).

analysed. It shows interglacial conditions characterised by high amounts of Carpinus (up to $40 \%$ ), shifting to woodland richer in Abies, then in Picea and dominated at least by Pinus and Betula. Fagus was not found, even though several samples have been analysed and all samples have been checked for pollen content. This sequence cannot resemble the sequences Lu-I-B from Ludwigshafen P34 or M-I-A, M-I-B, M-II, M-III-A, M-III-B from the Mannheim boreholes. It could possibly be correlated with Lu-I-C from Ludwigshafen P 34 and M-I-C from Mannheim UVB-3 (Fig. 8). The formation of a pine-birch forest marking the end of the interglacial was identified at Ludwigshafen-Maudach. If the correlation is correct, then the Mannheim Interglacial resembles two separate units. The lack of Celtis or Azolla allows that the interglacial can possibly be correlated with the Eemian so far.

In the cores from Mannheim three single samples with Fagus, Carpinus and Abies are present at a depth of approximately 29 34 m (M-I-A, M-III-A). Though single samples should be estimated very carefully this could be taken as a hint for a further Interglacial with Fagus above the Mannheim Interglacial.
The Mannheim Interglacial is divided into a lower sequence (M-I-C) with high values of Carpinus, Corylus, Ulmus, Quercus and Alnus and an upper sequence (M-I-B) with very high values of Alnus, rising values of Abies and lower values of Ulmus, Quercus, Carpinus, Corylus and Fagus (Fig. 6). A layer of sand and gravel is intercalated between these two sequences, pointing to an erosion phase and a possible discordance. The sequence M-II (borehole Mannheim UVB-1, Fig. 7) likely correlates with M-I-B. The notable dissimilarities in the pollen assemblages may have been caused by sedimentation under different conditions: standing water for M-I-B and flowing water for M-II. The single samples M-III-B may also correlate with M-I-B.

The sequences Lu-I-B with Fagus, Abies, Carpinus and Lu-I-C with Abies and Carpinus but without Fagus of Ludwigshafen P 34 can be tentatively correlated with the Mannheim Interglacial even though the profile is only partly analysed (Fig. 8).

The characteristic features of the Mannheim Interglacial are: occurrence of Fagus in the upper part;

occurrence of Celtis and Azolla; 
- lack of Early Pleistocene elements;

- lack of Pterocarya;

- bipartite sequence.

A correlation of the Mannheim Interglacial with the Eemian or Early Würmian is impossible due to the occurrence of Fagus, Celtis and Azolla (Beug, 1979; Drescher-Schneider, 2000a; Müller, 2000, 2001; Wegmüller, 1992; Beaulieu \& Reille, 1992). Since there are no Pliocene elements an Early Pleistocene position has to be rejected too. A correlation with the Holsteinian position is highly unlikely because of the high values of deciduous trees and the lack of Pterocarya (Müller, 1974; Grüger, 1983; Drescher-Schneider, 2000b). A position in MIS 7 cannot be rejected but is unlikely. Interglacials in MIS 7 are described at some sites in the Central Massif (France) or in northern Germany and show other patterns of vegetation development (Erd, 1973; Reille \& Beaulieu, 1995; Urban, 1995). However, these sites are located far away from the study area. Recently the interglacial profile of Meikirch II (Welten, 1982, 1988) was reinterpreted by Drescher and Preusser (Preusser et al., 2004) and the former 'Eemian' is now correlated with MIS 7. There are some similarities with the Mannheim Interglacial, but Celtis is not present at Meikirch. If the interglacial sequence of Ludwigshafen-Maudach can be correlated with the lower part of the Mannheim Interglacial than a correlation with Meikirch II is very unlikely. In the two lower Interglacials of Meikirch 'Holstein 1' and 'Holstein 2' Carpinus pollen is very rare, but it is present in Ludwigshafen-Maudach with values of up to nearly $40 \%$.

The spectra of the Mannheim Interglacial seem to correlate best with those known from the Cromerian Complex. However, a Cromerian I age is excluded because Eucommia has not been found in our investigated sections. Even so a correlation with Cromerian II (Zagwijn,1996) or Hunteburg (Hahne et al., 1994) seems highly unlikely because the very low counts of Carpinus. A tentative correlation of the Mannheim Interglacial with the Rhume (Salzderhelden BK20) Interglacial (Müller, 1986, 1992) or the Kärlich Interglacial (Urban, 1983; Bittmann, 1991) might be possible due to the occurrence of Celtis (even Celtis charcoal, Schoch in Urban, 1983), Fagus and Azolla as well as thermophilous deciduous trees.

Faunal remains of the $\mathrm{OZH}$ in the drilling MannheimLindenhof P 18 were assigned by Rähle (2005) to the Cromerian Complex. First pollen results from the same samples reveal a pollen flora with Abies, Carpinus, Fagus and Azolla which can possibly be correlated with the upper part of the Mannheim Interglacial. Furthermore malacological investigations from Engesser \& Münzing (1991) in the area of PhillipsburgMannheim also lead to the assignment of the $\mathrm{OZH}$ to the Cromerian Complex, at least in parts.

In a former interdisciplinary study (Von Koenigswald, 1988) an Eemian age for the upper clay (0ZH) was assumed. With the new studies in Schifferstadt, Mannheim and Ludwigshafen this theory can be rejected. Interesting in this context are the analyses of pollen and the dating of some samples from the OKL and OZH from the northern Upper Rhine Graben (Beug, 1988; Schweiss, 1988). From 16 pollen samples only two samples from Groß-Rohrheim (ca. $25 \mathrm{~km}$ north of Mannheim) show an interglacial pollen assemblage. Assuming that the two interglacial samples from the upper clay $(\mathrm{OZH})$ belong to the Younger Pleistocene, Beug (1988) assigned these two samples to the Eemian. In sample I 17 (Groß-Rohrheim) of the by Beug (1988) analysed section Ulmus (34\%), Carpinus (27\%), Abies $(8 \%)$, Corylus (7\%), Quercus (2\%) and Pinus (13\%) are present. Compared to Eemian profiles in southwestern Germany and the Vosges mountains (Frenzel, 1991; de Beaulieu \& Reille 1992; Müller 2000, 2001; Knipping, unpublished data) pollen assemblages with high values of Ulmus and Carpinus and low values of Quercus are unusual. In sample II 23 from GroßRohrheim (section analysed by Beug, 1988) Picea (40\%), Pinus (30\%), Abies (14\%), Quercus (7\%) but no Carpinus were noted. An Eemian age is very unlikely for this sample. In the Eemian profiles from Jammertal at 578 a.s.l (Müller, 2000), Füramoos at $662 \mathrm{~m}$ a.s.l (Müller, 2001) and Oberschwarzach at $696 \mathrm{~m}$ a.s.l (Knipping, unpublished data) the values of Abies and Carpinus decline at approximately the same time. It is very unlikely that in the considerably lower situated region of the Upper Rhine Graben (ca. $100 \mathrm{~m}$ a.s.l) Carpinus would not grow, but in stead would be able to survive in mountainous regions. Of further interest is the dating of 6 peat samples by the U/Th method during the study mentioned above (Beug, 1988; Schweiss, 1988). All samples show boreal conditions and gave ages of between $118 \mathrm{Ka}$ and $279 \mathrm{Ka}$. They were collected with a dredger below the groundwater table and therefore the stratigraphic position is not secure. However, it is highly probable that these samples are derived from the upper aquifer $(\mathrm{OKL})$. This means that the $\mathrm{OKL}$ sediments include deposits that cover the time span from MIS 7 to MIS 5, and the Würmian.

Below the sequences in Ludwigshafen assigned to the Mannheim Interglacial a further sequence Lu-I-D with Picea, Pinus, Quercus, Ulmus, Alnus, few Tilia and high values of fern spores has been observed. Until now no pollen of Fagus, Carpinus or Abies were found. Maybe this sequence represents a temperate interstadial. It resembles in part with the thermomere previous to the Rhume (synonym: Bilshausen) Interglacial in the drilling of GoHy 1270 as described by Müller (1992). He mentioned a cool forested sequence with mainly Pinus and lower values of Quercus and Alnus. A tentative correlation of the Mauer Interglacial with the sequence GoHy 1270 was made by Urban (1997). The sequence of Lu-I-D is analysed in parts only, therefore a reliable correlation with the sequences previous to the Ruhme or the Mauer Interglacial is not possible at the moment.

In the profile of Schifferstadt an almost complete interglacial sequence is recorded (S-I-A+B, Fig. 2). Due to the 
occurrence of Celtis in this Interglacial a correlation with the Eemian or Early Würmian is impossible (Beug, 1979; DrescherSchneider, 2000a; Müller, 2000, 2001; Wegmüller, 1992; Beaulieu \& Reille, 1992). A position in MIS 7 is unlikely. If we follow the arguments of Preusser et al. (2004) and correlate the former 'Eemian' in Meikirch II (Welten, 1982, 1988) with MIS 7 then the Schifferstadt Interglacial cannot be an equivalent because of the total lack of Fagus in the Schifferstadt samples. If both lower interglacial sequences 'Holstein 1 ' and 'Holstein 2 ' correlate with Schifferstadt we should assume higher values of Carpinus in the younger 'Holstein 2'. A further argument is the lack of Celtis at Meikirch. A Holsteinian position is very unlikely because of the high values of deciduous trees and the absence of Fagus and Pterocarya (Grüger, 1983; DrescherSchneider, 2000b). Since there are no Pliocene floral elements an Early Pleistocene position can also be rejected, too.

Characteristic for the Schifferstadt Interglacial (S-I-A, S-I-B) is the lack of Carpinus in the first optimum phase und a weak occurrence in the second phase. Pollen profiles without Carpinus were described by several authors (Harreskov and Ølgod: Andersen, 1965; Ferdynandów: Janczyk-Kopikowa, 1975; Ottostraße: Grüger, 1996; Hunteburg: Hahne, 1996; Surheide: Behre, 2004). The Schifferstadt Interglacial resembles the Ferdynandowian Interglacial in Poland (Janczyk-Kopikowa, 1975) and its equivalents (Rzechowski, 1996) rather well, although the sites are at a distance of several hundred kilometres. In the Ferdynandowian Interglacial high values of Corylus, Ulmus, Quercus and the absence of Carpinus are characteristic for the lower optimum. The same can be said for the Schifferstadt Interglacial. In the second optimum phase Carpinus is well represented in Ferdynandow while Abies is almost absent. In Schifferstadt Carpinus is weak and Abies is present with low values.

Due to high values of Corylus, Ulmus and Quercus the profile from Hunteburg (Hahne, 1996) is comparable with the first optimum phase in Schifferstadt except for a weak occurrence of Carpinus and a late spread of Abies at the end of the interglacial sequence at Hunteburg. Discussion about the accurate stratigraphic position of the Ferdynandowian Interglacial in relation to the marine isotope stages as well as to other interglacials lacking Carpinus discussion is continuing (Turner, 1996; Zagwijn, 1996; Behre, 2004).

The short sequence with Tsuga and low thermophilous elements at Schifferstadt S-I-C (Fig. 3) may be part of an interstadial or represents the end of an interglacial and is assigned to the 0ZH. In Schifferstadt Tsuga is present during those phases of interstadials when oceanic climatic conditions prevailed, usually in association with abundant Ericales. Tsuga does not occur in the pollen sequences from the continental and possibly cold climatic phases, characterised by Larix, Juniperus and Artemisia.
Tsuga is usually described as a characteristic Early Pleistocene floral element (Urban, 1978a; Müller, 1986; Lang, 1994). If this is true, then in Schifferstadt the OZH was formed, at least partly, during this time span. Currently it is not possible to assign the sequence with Tsuga at Schifferstadt (S-I-C) to a part of the Middle Pleistocene or to the Early Pleistocene e.g. the Bavelian (Zagwijn \& De Jong, 1984). The second possibility is more likely due to the high values of Ericales.

In the sequence from Mannheim M-I-C (Fig. 6) a single grain of Tsuga could be determined. Bludau (2001) also determined several pollen grains of Tsuga in the drilling from 'Mannheim Ergo BK 3' and he discussed a Cromerian age. For these interglacial sequences a correlation with the Early Pleistocene seems impossible. If the presence of Tsuga pollen can be confirmed in further studies of the Ludwigshafen cores, then we can reject Tsuga as an index fossil for the Early Pleistocene. Because of the warmer climate it cannot be precluded that this tree species did survive in the Upper Rhine Graben up to the Cromerian Complex even though it had become extinct in the northern part of Central Europe.

In contrast to the oceanic phase with Tsuga and Ericales mentioned above, several sections could be detected pointing to a continental climate indicated by Larix, Ephedra, Artemisia, Chenopodiaceae (S-I-D).

In several parts of the profiles from Schifferstadt, Mannheim and Ludwigshafen (Fig. 8, Knipping 2002, 2004a) pollen assemblages indicating boreal forests with Pinus, Picea and Betula are very common. These single, short sequences cannot be assigned with any certainty to known stratigraphic positions at the moment, but a combination of these characteristic patterns of vegetation change of oceanic or continental climates may enable a correlation with well dated time slices.

The pollen assemblages in PZ 2-4 from the Early Pleistocene sequence at Schifferstadt (S-I-E, Fig. 5) can probably be assigned to a part of the Tegelen A due to the occurrence of Fagus as well as Tertiary relicts (Eucommia, Tsuga, Pterocarya) (Zagwijn, 1963; Urban, 1978a). PZ 1 is possibly part of the Pretiglian, though this interpretation is uncertain due to the reworked pollen taxa. A warm climate can be assumed for $\mathrm{PZ}$ 2 with high values of Ulmus and a cooler climate for PZ 3 and PZ 4. Very unusual is the occurrence of Pinus cembra type at Schifferstadt, as this pollen type is lacking in most of the pollen diagrams described by other authors and assigned to the Tegelen Complex. Only Urban (1978b) had determined Pinus cembra type in the 'van Eyck-Interstadial' and correlated it with Tegelen C 5-6 (cf. Zagwijn, 1963). In the Frechen Interglacial (Urban, 1978a), correlated with Tiglian A, Pinus cembra type is absent. The single sample from the drilling Ludwigshafen $(161 \mathrm{~m})$ with pollen from Fagus, Tsuga, Pterocarya, and Carpinus may also be correlated with the Tiglian Complex (Tiglian A) (Urban, 1978a; Zagwijn, 1963). 


\section{Conclusions}

In the following a tentative correlation of the investigated sites is attempted.

Assuming that the sequence of Ludwigshafen-Maudach is an equivalent to the lower part of the Mannheim Interglacial (M-I-C, Lu-I-C) all investigated interglacial pollen assemblages are necessarily older than MIS 7. At the investigated sites there are no hints of Holsteinian, correlated now with MIS 9 (Geyh \& Müller, 2005). A possible assignment of the Mannheim Interglacial is to the Rhume (synonym: Bilshausen) Interglacial (Müller, 1992) and to its equivalent the Kärlich Interglacial (Urban, 1983; Bittmann, 1991). These sequences show just like the Mannheim Interglacial Fagus, Celtis and Azolla beside high pollen values of Abies, Carpinus, Quercus and Corylus. Bittmann \& Müller (1996) correlated the Kärlich with the Rhume Interglacial and assigned them to MIS 11 to the younger Cromerian Complex. A consequence of this correlation with the Mannheim Interglacial is that the pollen assemblages of M-I-A and M-III-A may date to a younger Interglacial. An assignment to a certain marine isotope stage is not possible yet. The sequence in Ludwigshafen (Lu-I-D) below the Mannheim Interglacial shows no traces of Abies, Carpinus or Fagus. A definite assignment is not possible yet, but resembling assemblages can be found in the sequence of Gorleben GoHy 1270 that precede the Rhume Thermomere (Müller, 1992). All above named sequences are derived from the $0 \mathrm{ZH}$ (Oberer Zwischenhorizont), the last one from the $0 \mathrm{ZH}$ is the Schifferstadt Interglacial for which also a position within the Cromerian Complex is assumed. The most likely correlation is with the Ferdinandów Interglacial (JanczykKopikowa, 1975) and in parts with the Hunteburg Interglacial (Hahne, 1996).

Tsuga is proven in the $\mathrm{OZH}$ of the Schifferstadt drilling. Further investigations may help to decide whether Tsuga is really a characteristic indicator of the Early Pleistocene or whether this species became extinct during the Middle Pleistocene. The last assumption seems to be more likely.

The intermediate layers $\mathrm{ZH} 2$ and $\mathrm{ZH} 3$ in the drilling of Ludwigshafen show to the current state of analysis only interstadial or stadial sequences. Early Pleistocene relicts are not present, a Middle Pleistocene age is therefore assumed.

Early Pleistocene sequences are present in the lower intermediate horizon (UZH). Pollen assemblages with Fagus, Tsuga and Eucommia are correlated within the Tiglian Complex (Tiglian A).

From the current state of knowledge a time span from younger Middle Pleistocene to the Würmian is not represented with longer sequences. This might be due to an intensive fluvial erosion phase and/or a decreased tectonic subsidence rate in the investigated area.

The preliminary correlation of the investigated sites (Fig. 8) leads to the conclusion that the $0 \mathrm{ZH}$ in the area Mannheim/
Ludwigshafen has definitely not been formed during a single specified time span. It is certainly not of Eemian age. In view of its thickness and position in the Upper Rhine Graben and due to the fact that it contains different Interglacials it might rather be of Cromerian age as already supposed in former investigations (Bludau, 1993; Engesser \& Münzing, 1991). Within the upper aquifer (OKL) Würmian, Eemian and at least parts of MIS 7 are present.

The deep drillings of Ludwigshafen Parkinsel with the current interdisciplinary studies (Hagedorn, 2004; Rolf, 2004; Weidenfeller \& Kärcher, 2008) may be a key for the reinterpretation of unconsolidated rocks in the Mannheim/ Ludwigshafen area.

\section{Acknowledgements}

I am indebted to the German Science Foundation and the Landesamt für Geologie und Bergbau Rheinland-Pfalz for supporting a part of the investigations. For fruitful discussions my thanks go to M. Weidenfeller (Landesamt für Geologie und Bergbau Rheinland Pfalz), E.-M. Hagedorn (Universität Köln) and D. Ellwanger (Landesamt für Geologie, Rohstoffe und Bergbau Baden-Württemberg). I am grateful to W. Rähle (Universität Tübingen) for the insight of unpublished Data. Thanks also to the reviewers, they gave helpful comments on the manuscript. Finally, I acknowledge S. Liner (Universität Hohenheim), A. Hildebrandt and M. Mays (Landesamt für Geologie und Bergbau Rheinland-Pfalz) for preparing the pollen samples and also E. Turner (RGZM Monrepos) and M. M. Weiss (Universität Hohenheim) for linguistic assistance.

\section{References}

Andersen, S.T., 1965. Interglacialer og interstadialer i Danmarks Kwartaer Medd. Dansk Geol. For. 15: 486-506.

Bartz, J., 1959. Zur Gliederung des Pleistozäns im Oberrheingraben. Zeitschrift Deutsche Geologische Gesellschaft 111: 653-661.

Bartz, J., 1976. Quartär und Jungtertiär im Raum Rastatt. Jahreshefte des Geologischen Landesamts Baden-Wüttemberg 18: 121-178.

Bartz, J., 1982. Quartär und Jungtertiär II im Oberrheingraben im Großraum Karlsruhe. Geologisches Jahrbuch A 63: 237 pp.

Beaulieu, J.L. de \& Reille, M., 1992. The Last Climatic Cycle at La Grande Pile (Vosges, France). A new Pollen profile. Quaternary Science Reviews 11: 431 438.

Behre, K.-E., 2004. Das mittelpleistozane Interglazial von Surheide. Eiszeitalter und Gegenwart 54: 36-47

Beug, H.-J., 1979. Vegetationsgeschichtlich-pollenanalytische Untersuchunger am Riß/Würm-Interglazial von Eurach am Starnberger See. Geologica Bavarica 80: 91-106.

Beug, H.-J., 1988. Über die pollenanalytische Datierung einiger jungpleistozäner Proben aus der Oberrheinebene bei Darmstadt. In: Von Koenigswald, W. (ed.): Zur Paläoökologie des letzten Interglazials im Nordteil der Oberrheinebene. Paläoklimaforschung 4: 105-116 
Bittmann, F., 1991. Vegetationsgeschichtliche Untersuchungen an mittel- und jungpleistozänen Ablagerungen des Neuwieder Beckens (Mittelrhein). Jahrbuch des römisch-germanischen Zentralmuseums Mainz 38: 83-190.

Bittmann, F. \& Müller, H., 1996. The Kärlich Interglacial site and its correlation with the Bilshausen sequence. In: Turner, C. (ed.): The early Middle Pleistocene in Europe. Balkema (Rotterdam): 187-193.

Bludau, W., 1993. Biostratigraphische Untersuchungen an Sedimenten aus dem mittleren Oberrheingraben Vorläufige Ergebnisse. Jahreshefte des Geologischen Landesamts Baden-Wüttemberg 35: 395-406.

Bludau, W., 1995. Altpleistozäne Warmzeiten im Alpenvorland und im Oberrheingraben - Ein Beitrag der Palynologie zum 'Uhlenberg-Problem'. Geologica Bavarica 99: 119-133.

Bludau, W., 2001. Preliminary results of pollenanalytical investigations in the northern part of the Upper Rhine Valley. internal report, Denzlingen: 2 pp.

Drescher-Schneider, $R$., 2000a. Die Vegetations- und Klimaentwicklung im Riß/ Würm-Interglazial und im Früh- und Mittelwürm in der Umgebung von Mondsee. Ergebnisse der pollenanalytischen Untersuchungen. Mitteilungen Kommission Quartärforsch Österreichische Akademie der Wissenschaften 12: 39-92.

Drescher-Schneider, R., 2000b. 2. Halt: Kiesgrube Thalgut: Pollen- und großrestanalytische Untersuchungen. In: Kelly, M., Linden, U. \& Schlüchter, Chr., Exkursionsführer DEUQUA 2000, Eiszeitalter und Alltag, Bern 6 - 8 September 2000: $128-136$.

Engesser, W. \& Münzing, K., 1991. Molluskenfaunen aus Bohrungen im Raum Phillipsburg-Mannheim und ihre Bedeutung für die Quartärstratigraphie des Oberrheingrabens. Jahreshefte des Geologischen Landesamts BadenWüttemberg 33: 97-117.

Erd, K., 1973. Pollenanalytische Gliederung des Pleistozäns der Deutschen Demokratischen Republik. Zeitschrift für Geologische Wissenschaften. 1: 1087-1103.

Frenzel, B., 1991. Über einen frühen letzteiszeitlichen Vorstoß des Rheingletschers in das deutsche Alpenvorland. In: Frenzel, B. (ed.): Klimageschichtliche Probleme der letzten 130000 Jahre. Paläoklimaforschung 1: 377-400.

Geyh, M.A. \& Müller, H., 2005. Numerical 230Th/U dating and a palynological review of the Hosteinian/Hoxnian Interglacial. Quaternary Science Reviews 24: $1861-1872$

Grüger, E., 1983. Untersuchungen zur Gliederung und Vegetationsgeschichte des Mittelpleistozäns am Samerberg in Oberbayern. Geologica Bavarica 84: 21-40.

Grüger, E., 1996. Palynostratigraphy of the Middle Pleistocene sequence from Göttingen, Otto-Strasse. In: Turner, C. (ed.): The early Middle Pleistocene in Europe. Balkema (Rotterdam): 173-180.

Grüger, E., Jordan, H., Meischner, D. \& Schlie, P., 1994. Sedimente mehrerer mittelpleistozäner Warmzeiten in Göttingen, Bohrungen Ottostraße und Akazienweg. Geologisches Jahrbuch A 134: 167-210.

Hagedorn, E.-M., 2004. Sedimentpetrographie und Lithofazies der jungtertiären und quartären Sedimente im Oberrheingebiet. Dissertation Universität zu Köln: 248 pp. http://kups.ub.uni-koeln.de/volltexte/2004/1253/

Hagedorn, E.-M. \& Boenigk, W., 2004. Zur Petrographie pliozäner und pleistozäner Sedimente am Oberrhein. DEUQUA meeting 30 August - 3 September 2004, Nijmegen, the Netherlands Abstract Volume: 40
Hagedorn, E-M. \& Boenigk W., 2008. New evidence of the Pliocene and Quaternary sedimentary and fluvial history in the Upper Rhine Graben on basis of heavy mineral analysis. Netherlands Journal of Geosciences 87/1: 21-32.

Hahne, J., 1996. The interglacial site of Hunteburg near Quakenbrück (NW Germany). In: Turner, C. (ed.): The early Middle Pleistocene in Europe. Balkema (Rotterdam): 181-186.

Hahne, J., Mengeling, H., Merkt, J. \&. Gramann F., 1994. Die HunteburgWarmzeit ('Cromer-Komplex') und Ablagerungen der Elster-, Saale- und Weichsel-Kaltzeit in der Forschungsbohrung Hunteburg GE 58 bei Osnabrück. Geologisches Jahrbuch A 134: 117-165.

Hottenrott, M., 1995. Zur Pliozän/Pleistozän-Grenze im nördlichen Oberrheingraben bei Eich (Bl. 6216 Gernsheim) anhand neuer Bohrergebnisse. Jahrbuch Nassauischer Verein Naturkunde 116: 41-64.

Janczyk-Kopikowa, Z., 1975. Flora interglacjalu Mazoweckiego w Ferdynandowie. Biuletyn Institut Geologiczny (Warszawa) 290: 1-94.

Kärcher, T., 1987. Beiträge zur Lithologie und Hydrogeologie der Lockergesteinsablagerungen (Pliozän, Quartär) im Raum Frankenthal, LudwigshafenMannheim, Speyer. Jahresberichte und Mitteilungen des Oberrheinischen Geologischen Vereins. N.F. 69: 279-320.

Knipping, M., 2002. Pollenanalytische Untersuchungen am Profil 'Schifferstadt BK 30c GM'. Arbeitsbericht Geologisches Landesamt Rheinland-Pfalz (Mainz): $11 \mathrm{pp}$.

Knipping, M., 2004a. Pollenanalytische Untersuchungen an einem mittelpleistozänen Interglazial bei Mannheim. Tübinger Geowissenschaftliche Arbeiten D 10: 199-217.

Knipping, M., 2004b. Pollenanalytische Untersuchungen an tiefen Kernbohrungen im nördlichen Oberrheingraben. DEUQUA meeting 30 August - 3 September 2004, Nijmegen, the Netherlands Abstract Volume: 52.

Küttel, M., Löscher, M. \& Hölzer, A., 1986. Ergebnisse paläobotanischer Untersuchungen zur Stratigraphie und Ökologie des Würms im Oberrheingraben zwischen Karlsruhe und Mannheim. Eiszeitalter und Gegenwart 36: $75-88$

Lang, G., 1994. Quartäre Vegetationsgeschichte Europas. G. Fischer (Stuttgart): $462 \mathrm{pp}$.

Menke, B., 1975. Vegetationsgeschichte und Florenstratigraphie Nordwestdeutschlands im Pliozän und Frühquartär. Geologisches Jahrbuch A 26: 3-151.

Müller, H., 1974. Pollenanalytische Untersuchungen und Jahresschichtenzählungen an der holsteinzeitlichen Kieselgur von Munster-Brehloh. Geologisches Jahrbuch A 21: 107-140.

Müller, H., 1986. Altquartäre Sedimente im Deckgebirge des Salzstockes Gorleben. Zeitschrift Deutsche Geologische Gesellschaft 137: 85-95.

Müller, H., 1992. Climate changes during and at the end of the interglacials of the Cromerian Complex. In: Kukla, G.J. \& Went, E. (eds): Start of a Glacial. NAT0 ASI Series 13. Springer (Berlin, Heidelberg): 55-69.

Müller, U., 2000. A Late-Pleistocene pollen sequence from the Jammertal, south-western Germany with particular reference to location and altitude as factors determining Eemian forest composition. Vegetation History and Archeobotany 9: 125-131.

Müller, U., 2001. Die Vegetations- und Klimaentwicklung im jüngeren Quartär anhand ausgewählter Profile aus dem südwestdeutschen Alpenvorland. Tübinger Geowissenschaftliche Arbeiten D 7: $118 \mathrm{pp}$ 
Preusser, F., Drescher-Schneider, R., Fiebig, M. \& Schlüchter, Ch., 2004. Re-Interpretation der Meikirch-Bohrungen, Aaretal, und Konsequenzen für die Quartärstratigraphie in der Schweiz. DEUQUA meeting 30 August 3 September 2004, Nijmegen, the Netherlands Abstract Volume: 67.

Rähle, W., 2005. Eine mittelpleistozäne Molluskenfauna aus dem Oberen Zwischenhorizont des nördlichen Oberrheingrabens (Bohrung MannheimLindenhof). Mainzer Geowissenschaftliche Mitteilungen 33: 9-20.

Reille, M. \& De Beaulieu, J.-L., 1995. Long Pleistocene Pollen Records from the Praclaux Crater, South-Central France. Quaternary Research 44: 205-215.

Rolf, C., 2004. Magnetische Eigenschaften quartärer Sedimente (Bohrung Ludwigshafen-Parkinsel). DEUQUA meeting 30 August - 3 September 2004, Nijmegen, the Netherlands Abstract Volume: 72.

Rolf C., Hambach, U. \& Weidenfeller, M., 2008. Rock and palaeomagnetic evidence for the Plio-Pleistocene palaeoclimatic change recorded in Upper Rhine Graben sediments in the northern Upper Rhine Graben, Germany. Netherlands Journal of Geosciences 87/1: 41-50.

Rzechowski, J., 1996. The Ferdynandowian Interglacial and its stratigraphical position in the Middle Pleistocene in Europe. In: Turner, C. (ed.): The early Middle Pleistocene in Europe. Balkema (Rotterdam): 279-294.

Schedler, J., 1981. Vegetationsgeschichtliche Untersuchungen an altpleistozänen Ablagerungen in Südwestdeutschland. Dissertationes Botanicae 58: 158 pp.

Schweiss, D., 1988. Jungpleistozäne Sedimentation in der nördlichen Oberrheinebene. In: Von Koenigswald, W. (ed.): Zur Paläoökologie des letzten Interglazials im Nordteil der Oberrheinebene. Paläoklimaforschung 4: 19-78.

Turner, C., 1996. A brief survey of the early Middle Pleistocene in Europe. In: Turner, C. (ed.): The early Middle Pleistocene in Europe. Balkema (Rotterdam): 295-317.

Urban, B., 1978a. The Interglacial of Frechen I/Rheinland - a section of the Tiglian A-Type. Geologie en Mijnbouw 57: 401-406.

Urban, B., 1978b. Vegetationsgeschichtliche Untersuchungen zur Gliederung des Altquartärs der Niederrheinischen Bucht. Sonderveröffentlichung Geologisches Institut Universität Köln 34: 165pp.

Urban, B., 1983. Biostratigraphic correlation or the Kärlich Interglacial, northwestern Germany. Boreas 12: 83-90.

Urban, B., 1995. Palynological evidence of younger Middle Pleistocene Interglacials (Holsteinian, Reinsdorf and Schöningen) in the Schöningen open cast lignite mine (eastern Lower Saxony, Germany). Mededelingen Rijks Geologische Dienst 52: 175-185.

Urban, B., 1997. Pollenanalytische Untersuchungen an der Homo erectus heidelbergensis-Fundstelle Mauer. In: Beinhauer, K.W. \& Wagner G.A. (eds): Homo heidelbergensis. Das Auftreten des Menschen in Europa. Universitätsverlag C. Winter (Heidelberg): 37-39.

Urban, B. 2006. Interglacial pollen records from Schöningen, north Germany. In: Sirocko, F., Litt, T., Claussen, M., Sanchez-Goni, M.F. (eds): The climate of past interglacials. Elsevier (Amsterdam): 417-444.

Von Koenigswald, W. (ed.), 1988. Zur Paläoökologie des letzten Interglazials im Nordteil der Oberrheinebene. Paläoklimaforschung 4: 327 pp.

Wegmüller, S., 1992. Vegetationsgeschichtliche und stratigraphische Untersuchungen an Schieferkohlen des nördlichen Alpenvorlandes. Denkschriften Schweizer Akademie Naturwissenschaften 102: 82 pp.
Weidenfeller, M. \& Kärcher, T., 2004. Terrassen, Kieslager und Zwischenhorizonte - Neue Aspekte zur geologisch-hydrogeologischen Gliederung der quartären Sedimente im linksrheinischen Teil des nördlichen Oberrheingrabens. DEUQUA meeting 30 August - 3 September 2004, Nijmegen, the Netherlands. Abstract Volume: 88.

Weidenfeller, M. \& Kärcher, Th., 2008. Tectonic influence on fluvia preservation: Aspects of the architecture of Middle and Late Pleistocene sediments in the northern Upper Rhine Graben, Germany. Netherlands Journal of Geosciences 87/1: 33-40.

Welten, M., 1982. Pollenanalytische Untersuchungen im Jüngeren Quartär des nördlichen Alpenvorlandes der Schweiz. Beiträge zur Geologischen Karte der Schweiz Neue Folge 156: 174 pp.

Welten, M., 1988. Neue pollenanalytische Ergebnisse über das Jüngere Quartär des nördlichen Alpenvorlandes der Schweiz (Mittel- und Jungpleistozän). Beiträge zur Geologischen Karte der Schweiz Neue Folge 162: 40 pp.

Zagwijn, W.H., 1963. Pollen-analytic investigations in the Tiglian of the Netherlands. Mededelingen van de Geologische Stichting N.S. 16: 49-71.

Zagwijn, W.H., 1996. The Cromerian Complex Stage of the Netherlands and correlation with other areas in Europe. In: Turner, C. (ed.): The early Middle Pleistocene in Europe. Balkema (Rotterdam): 145-172.

Zagwijn, W.H. \& De Jong, J., Die Interglaziale von Bavel und Leerdam und ihre stratigraphische Stellung im Niederländischen Früh-Pleistozän. Mededelingen Rijks Geologische Dienst 37: 155-169. 